\title{
Peter Förster, Transsexualität und ihre Auswirkungen auf die Ehefähigkeit. Eine kanonistische Untersuchung, EOS Verlag, Sankt Ottilien 2013, ss. 192
}

W 2013 r. w niemieckim Wydawnictwie EOS Verlag ukazała się interesująca pozycja autorstwa Petera Förstera, poświęcona problematyce wpływu transseksualizmu na niezdolność osoby do zawarcia małżeństwa. Monografia składa się z czterech rozdziałów.

Rozdział I, posiadający charakter wprowadzający, został zatytułowany „Humanwissenschaftliche Erkentnisse zum Phänomen Transseksualität”. W tej części studium Förster podszedł do interesującego go zagadnienia $\mathrm{z}$ różnych aspektów, jakimi są spojrzenie na ten fenomen $z$ historycznego i kulturowego punktu widzenia oraz ujęcie tego problemu $z$ aspektu nauk medycznych i psychologicznych. Konkludując swe rozważania stwierdził, iż przeprowadzona eksploracja badawcza wykazała, iż rozróżnienie pomiędzy transseksualizmem a transwestytyzmem w wiekach poprzednich było niemożliwe, gdyż w tym czasie nie wypracowano jeszcze precyzyjnej definicji transseksualizmu. Transseksualizm bowiem, jako odrębna jednostka chorobowa, został wyodrębniony przez seksuologów dopiero w XX wieku. Jak pisze Autor, transseksualizm jako zaburzenie w naukach medycznych jest młodym fenomenem (junges Phönomen). Obecnie definiuje się je jako trwałą i długotrwałą identyfikację z płciowością przeciwną.

W rozdziale II zasadniczym przedmiotem zainteresowania Förstera stał się problem prawnego odniesienia do transseksualizmu w Niemczech (Das rechliche Umgang mit Transseksualität in Duetschland). Prezentując tę kwestię na początku zwrócił on uwagę, iż 
w prawie niemieckim brak jest jednoznacznych definicji męskości oraz kobiecości. Po tej konstatacji ukazał genezę i dokonał szczegółowej interpretacji niemieckiej ustawy odnoszącej się do transseksualizmu oraz związanego $\mathrm{z}$ nim orzecznictwa, jaką jest wydany w dniu 10 września 1980 r. akt prawny „Gestetz über die Änderung der Vornamen und die Festellung der Geschlechtzugehörigkeit in besonderen Fällen (Transsexuellengesezt)".

Oceniając treści zawarte $w$ recenzowanym rozdziale pragnę zauważyć, iż poza zakresem pozostają dwa wątki zamieszczone w drugiej jej części. Pierwszy z nich dotyczy orzecznictwa europejskich trybunałów (Europejski Trybunał Sprawiedliwości, Europejski Trybunał Praw Człowieka); w drugim natomiast zatytułowanym „Transseksualität in anderen Rechtsordnungen” uwaga Autora koncentruje się wokół ustawodawstwa funkcjonującego w innych krajach (Australia, Belgia, Finlandia, Włochy, prowincje Kanady, Holandia, Szwecja, Turcja, Anglia i Irlandia Północna). Moim zdaniem, w tym wypadku optymalnym wyjściem byłoby przedstawienie tej problematyki w odrębnym rozdziale lub też sformułowanie nieco inaczej tytułu rozdziału II.

Rozdział III nosi tytuł „Transseksualität und Theologie”. W tej części studium Autor zajął się stanowiskiem moralistów w interesującej go kwestii. Przedstawiając problematykę transseksualizmu z perspektywy poglądów przedstawicieli tej dyscypliny teologicznej w pierwszym rzędzie spostrzegł on, że w teologii moralnej dominuje stanowisko, w myśl którego koncepcja dwupłciowości wynika z prawa naturalnego. Förster jednak wykazał, iż nie wszyscy uczeni podzielają ten pogląd. W swym wywodzie przywołał on opinie takich postaci, jak Ch. Ant, która sprzeciwia się determinizmowi biologicznemu, B. Ashley, J. Deblouis, K. O’Rourke, którzy poszukują odpowiedzi na pytania, czy operacja zmiany płci rzeczywiście jest ingerencją w cielesność ludzką i jej integralność?, oraz S. Goertz, negującą tezę, iż na skutek ingerencji medycznej dochodzi do rozdźwięku pomiędzy ciałem i ludzkim duchem.

W drugiej części rozdziału Autor przywołał dokumenty Stolicy Apostolskiej wydane głównie przez Kongregację Nauki Wiary ukazując stanowisko Kościoła w interesującej go kwestii oraz stwierdził, 
iż nie zostało ono wyraźnie wyrażone. Merytorycznie żadnych moich zastrzeżeń nie budzi podjęcie tego wątku. Uważam, iż tematyka ta została jednak niewłaściwie umiejscowiona w kompozycji studium. Pragnę zauważyć, iż wspomniane akty Stolicy Apostolskiej mają przede wszystkim charakter prawny, dlatego też powinny się znaleźć w strukturze następnego rozdziału, który ma właśnie taki charakter.

W rozdziale IV opublikowanym pod tytułem „Transseksualität und Ehefähigkeit” obiektem uwagi Autora stał się problem wpływu transseksualizm na niezdolność konsensualną do zawarcia małżeństwa. Swe rozważania Förster osadził w szerszym kontekście. Rozpoczął je bowiem, jak to się zwykle czyni w monografiach poruszających tematykę niezdolności konsensualnej, od prezentacji w syntetyczny sposób kwestii niezdolności konsensualnej, ujętej w opcji kan. 1095 KPK; po czym skupił uwagę na wątkach niezwykle istotnych, jakimi są orzecznictwo Roty Rzymskiej oraz orzecznictwo trybunałów niemieckich. Badając orzecznictwo Trybunału Apostolskiego skonstatował on, iż wydał on tylko pięć wyroków w których transseksualizm stanowił przyczynę niezdolności do zawarcia małżeństwa; nadmienił te $\dot{z}$, iż w żadnej z prowadzonych spraw nie miała jednak miejsca operacja zmiany płci. Dowiódł on, że nie we wszystkich orzeczeniach wyraźnie rozróżniono pomiędzy transseksualizmem a transwestytyzmem. Ponadto wskazał, iż do wyroku c. Giannecchini z 21 lutego 1995 r. w Rocie Rzymskiej nie wydano żadnego wyroku za nieważnością małżeństwa.

Z badań przeprowadzonych przez Förstera nad orzekaniem niemieckich sądów wynika, iż przeprowadzono w nich zaledwie siedemnaście spraw, w których występował transseksualizm. Przy tym pragnę zauważyć, iż $\mathrm{w}$ przeciwieństwie do poprzedniego passusu, w którym szczegółowo omówił on poszczególne sprawy rotalne, w tym wątku zastosował on inną metodologię, mianowicie zupełnie zasadnie, przedstawił poszczególne zagadnienia związane z orzekaniem trybunałów niemieckich. Omawiając ten problem Autor zwrócił uwagę, iż w większości prowadzonych spraw osoba cierpiąca na tego typu zaburzenia nie była w stanie wypełnić obowiązków związanych 
ze stworzeniem wspólnoty małżeńskiej. W jednej tylko sprawie osoba zalegalizowała zmianę płci zgodnie z prawem niemieckim.

Analiza materiału sądowego stała się dla Autora podłożem do dalszych rozważań kanonistycznych. W końcowej części rozdziału Förster zajął się wątkiem kluczowym dla tego opracowania, jakim jest wpływ transseksualizmu na niezdolność konsensualną osoby do zawarcia małżeństwa, ujmując go z trzech perspektyw, to z znaczy, z aspektu niezdolności do wyrażenia konsensu małżeńskiego, $\mathrm{z}$ aspektu niezdolności do podjęcia istotnych obowiązków małżeńskich, a także $\mathrm{z}$ aspektu niezdolności będącej następstwem dokonanej operacji zmiany płci.

Konkludując pragnę stwierdzić, iż pomimo pewnych braków natury systematyzacyjnej, treści zawarte w prezentowanej monografii stanowią cenny wkład w kanonistyczny obszar badań nad niezdolnością konsensualną do zawarcia małżeństwa. Peter Förster przedstawił interesującą go problematykę wieloaspektowo. Czytając tą pozycję w pierwszej chwili ma się wrażenie, iż niektóre z przedstawionych wątków są niepotrzebne, gdyż pozostają one poza zakresem tematyki określonej w tytule monografii; taka uwaga dotyczy zwłaszcza kwestii podjętej w rozdziale II poświęconej ustawodawstwu niemieckiemu. W moim przekonaniu, z perspektywy całego dzieła rozważanie tych zagadnień było jednak konieczne, bowiem tylko takie podejście do omawianej tematyki umożliwiło Autorowi wieloaspektowe osadzenie na właściwym podłożu problematyki kluczowej tego dzieła, jaką stanowi wpływ transseksualizmu na niezdolność konsensualną do zawarcia małżeństwa. 